\title{
Biological Control of Damping off and Foot Rot of Chilli Using an Indigenous Trichoderma harzianum
}

Md. Mukul Islam ${ }^{1}$, Md. Abu Zafor ${ }^{2}$, Md. Emran Khan Chowdhury ${ }^{3}$, A.T.M. Shafiqul Islam ${ }^{1}$, Md. Mohidul Hasan ${ }^{1 *}$

${ }^{1}$ Department of Plant Pathology, Hajee Mohammad Danesh Science and Technology University (HSTU), Dinajpur-5200, Bangladesh

${ }^{2}$ Department of Soil Science, Hajee Mohammad Danesh Science and Technology University (HSTU), Dinajpur-5200, Bangladesh

${ }^{3}$ Senior Scientific Officer, Bangladesh Agricultural Research Institute, Gazipur, Bangladesh

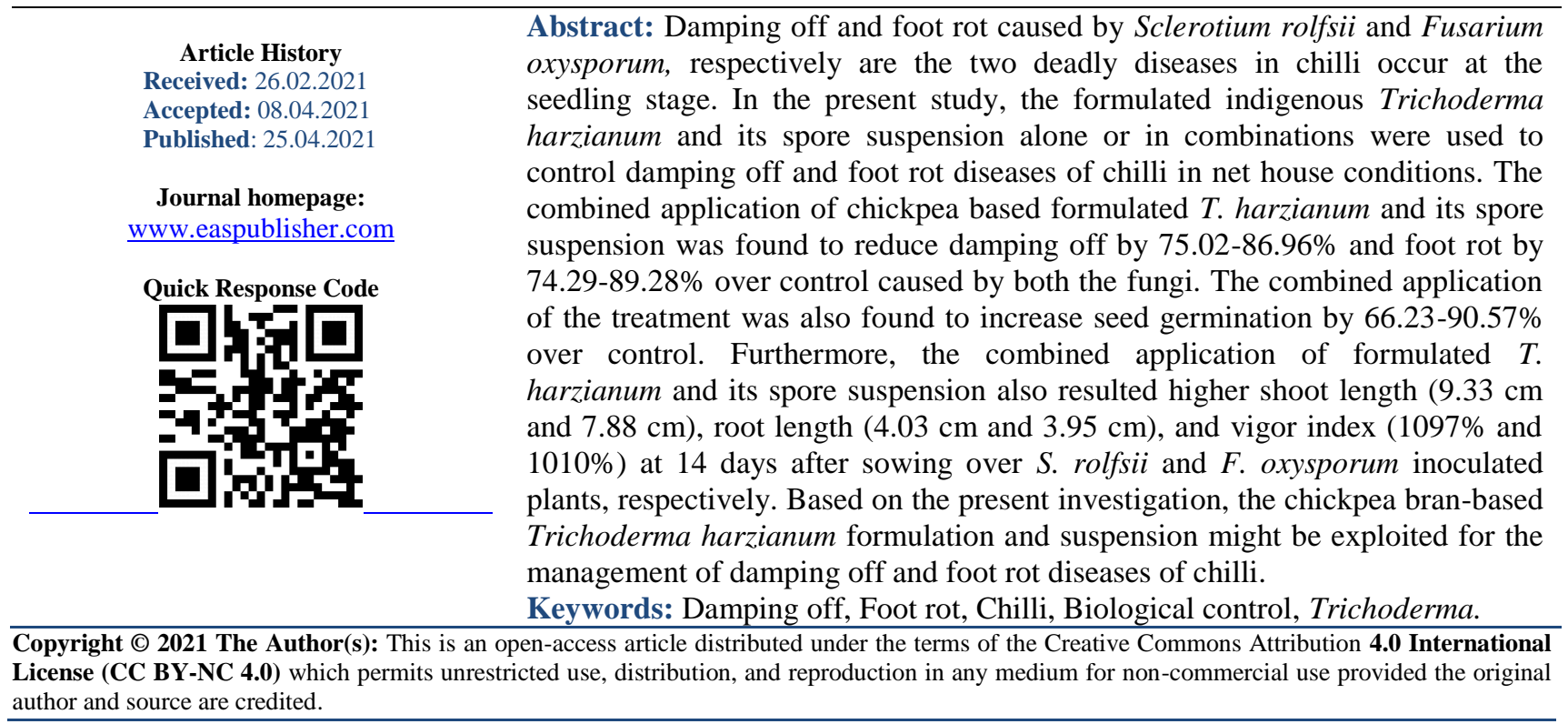

\section{INTRODUCTION}

Chilli (Capsicum annum L.) is the secondranked spice crop after onion in Bangladesh cultivated year round. In Bangladesh, the annual production of chilli was 1, 05,764 and 31,108 metric tons in the Rabi and Kharif season, covering 2, 11,824 and 43,637 acres of agricultural land, respectively [1]. However, the potential yield of chilli in Bangladesh is far low in comparison to other chilli producing countries. For the low yield of chilli, diseases play the most vital role and about 15 diseases of chilli including 12 fungal were reported in Bangladesh [2]. Among the fungal diseases, damping off and foot rot are the prominent and deleterious diseases caused by different soil-borne pathogens like Sclerotium rolfsii, Fusarium oxysporum, Rhizoctonia solani, Pythium sp. etc. [3].

Traditionally the growers use chemicals to control crop diseases and the long time unjudicial using of chemicals showed hazardous impacts on the environment and human health [4]. However, now the consumers are very concern about the health and environmental impact of the chemicals and therefore, researchers are moving to explore alternative ways of controlling the crop diseases without chemicals.

Biological control of plant diseases using different beneficial fungi and bacteria has gained significant interest as an effective alternative to chemical due to their durability, cost-effectiveness, and environmental safety nature $[5,6]$. Trichoderma is one of the most studied and available fungus popularly used as a biological control agent against different crop diseases including damping off and foot rot caused by Sclerotium, Fusarium, Rhizoctonia, Pythium, Phytophthora etc. [7-9]. Trichoderma sp. employs various mechanisms like competition, antibiosis, parasitism, mycoparasitism, secretion of various enzymes, and hyphal interaction to combat different plant pathogens [10]. Along with the antagonistic efficacy against the respective pathogen, Trichoderma also plays the role in the increasing of seed germination, crop growth, and yield of the crop plants [11]. However, the repeated and long time using of the same strain of Trichoderma leads to the loss of its potentiality as a biocontrol agent. Hence, it needs to keep searching 
for new potential strains with good efficacy of controlling damping off and foot rot diseases. Therefore, the present study has been designed to investigate the bio-efficacy of indigenous Trichoderma sp. against damping off and foot rot in chilli in the northern region of Bangladesh.

\section{Materials ANd Methods}

The net house study of the bio-efficacy of Trichoderma sp. against damping off and foot rot of chilli was carried out in the Department of Plant Pathology, Hajee Mohammad Danesh Science and Technology University (HSTU), Dinajpur during 20172018.

\section{Collection of the antagonist}

T. harzianum was collected from the Department of Plant Pathology, which was previously isolated, identified, and preserved at $4{ }^{\mathrm{O}} \mathrm{C}$.

\section{Collection, isolation, and identification of Sclerotium rolfsii and Fusarium oxysporum}

Chilli plants having characteristic damping off and foot rot symptoms were collected, washed thoroughly with running tap water, and cut into small pieces with the help of scissors. The cut pieces were then surface sterilized with $0.1 \%$ mercuric chloride solution for a min. following three times washing with sterilized double-distilled water. The pieces were then aseptically placed on Petri plates containing potato dextrose agar (PDA) and incubated for 7 days at $28 \pm 2$ ${ }^{0} \mathrm{C}$. After colonization, the superficial growth of the fungi was sub-cultured for purification and identified morphologically under a compound microscope [12, 13] and preserved at $4{ }^{0} \mathrm{C}$ until further use.

\section{Preparation of $\boldsymbol{T}$. harzianum formulation}

The commonly available substrate, chickpea brans were used to formulate the indigenous $T$. harzianum. In brief, $200 \mathrm{~g}$ of overnight soaked chickpea bran were taken in $500 \mathrm{~mL}$ Erlenmeyer flasks and autoclaved for $15 \mathrm{~min}$ at $121{ }^{0} \mathrm{C}$ with $15 \mathrm{psi}$. Subsequently, chickpea bran was inoculated with actively growing 10-12 mycelial discs of T. harzianum ( $6 \mathrm{~mm}$ in dia). After vigorous mixing, the flasks were left undisturbed for 21 days at $28 \pm 2{ }^{0} \mathrm{C}$. Finally, the colonized substrates were taken out and kept in a laminar air flow chamber for drying and stored in sterile poly bags at $4{ }^{\mathrm{O}} \mathrm{C}$ until further use.

\section{Preparation of $T$. harzianum suspension}

For the preparation of spore suspension, $10 \mathrm{~mL}$ sterilized double distilled water was poured onto fullgrown T. harzianum Petri plates and the surface was scrapped smoothly with the help of a sterilized glass rod. The suspension was then sieved carefully using a double-layered sterile muslin cloth and taken in a 400 $\mathrm{mL}$ beaker containing double distilled water. Later, a drop of Tween-20 was added to the suspension and the spores were counted to make $2.45 \times 10^{7}$ conidia/mL using a hemocytometer [14].

Preparation of $S$. rolfsii and $F$. oxysporum inoculum Overnight soaked wheat grains were used for the preparation of both $S$. rolfsii and $F$. oxysporum inoculum. In brief, $100 \mathrm{~g}$ moisten wheat grains were taken in a $500 \mathrm{~mL}$ Erlenmeyer flask and autoclaved for $15 \mathrm{~min}$ at $121^{\circ} \mathrm{c}$ with $15 \mathrm{psi}$. After that, 7-10 mycelial discs $(6 \mathrm{~mm}$ in dia) of vigorously growing culture of both the fungi were transferred aseptically to the flasks, mixed, and left undisturbed for 21 days at $28 \pm 2{ }^{0} \mathrm{C}$. After colonization, the flasks were taken out and allowed to dry in a laminar air flow chamber and stored in a refrigerator at $4{ }^{\circ} \mathrm{C}$ for further use by using polybags [15].

\section{Net house study to control damping off and foot rot of chilli}

To evaluate the bio-efficacy of native $T$. harzianum against damping off and foot rot of chilli, two sets of experiments were conducted separately for $S$. rolfsii and $F$. oxysporum. A mixture of 1:2 ratios of sterilized soil $(4 \mathrm{~kg})$ and well-decomposed cow dung was used to fill the individual pots $\left(18 \times 12 \times 4 \mathrm{~cm}^{3}\right)$. The treatment combinations used for both the fungal pathogens were as follows: healthy control (without fungal pathogen and Trichoderma); control (only fungal pathogen); formulated T. harzianum + fungal pathogen; $T$. harzianum spore suspension + fungal pathogen and formulated $T$. harzianum $+T$. harzianum spore suspension + fungal pathogen. Fifty chilli seeds were sown in each pot and all the treatments applied thrice following a completely randomized design. Formulated T. harzianum and the fungal pathogens were applied (@ $20 \mathrm{~g} / \mathrm{kg}$ of soil) before 7 days of sowing where $T$. harzianum spore suspension was sprayed (@ $\left.2.45 \times 10^{7} \mathrm{cfu} / \mathrm{mL}\right)$ after three days of sowing. Data were recorded on damping off $(\%)$, foot rot $(\%)$, and seed germination (\%) at 7 and 14 days after sowing (DAS). While data on different growth attributes [shoot length $(\mathrm{cm})$, root length $(\mathrm{cm})$, and vigor index $(\%)]$ were collected at 14 DAS. Vigor index was computed following the equation [16]:

Vigor index $(\%)=($ Mean shoot length + Mean root length) $\times \%$ Germination

\section{Statistical Analysis}

Collected data were analyzed using the MSTAT-C package program. The means were estimated by DMRT (Duncan Multiple Range Test) at $5 \%$ level of significance [17].

\section{RESULTS AND DisCUSSION}

The disease management potentiality of indigenous $T$. harzianum was evaluated against damping off and foot rot diseases of chilli caused by both $S$. rolfsii and $F$. oxysporum. The used formulated 
T. harzianum alone or in combination with its spore suspension were found to reduce both damping off and foot rot of chilli. Besides, the application of $T$. harzianum also increased the seed germination and other agronomic traits that have a direct link to the yield of chilli.

When the plants inoculated with $S$. rolfsii, the combined application of formulated T. harzianum and its spore suspension was found to show minimum damping off (1\% and $2.33 \%)$ and foot rot $(1.33 \%$ and
$3 \%$ ) in comparison to formulated T. harzianum (3.67\% and $4.67 \%$ of damping off and $3.67 \%$ and $5.67 \%$ of foot rot); T. harzianum spore suspension $(5.33 \%$ and $6 \%$ of damping off and $7 \%$ and $7.67 \%$ foot rot) alone at 7 and 14 DAS, respectively. The combined treatment also yielded the maximum seed germination $(80.67 \%$ and $82 \%$ ) in comparison to formulated T. harzianum (59\% and $61.33 \%$ ) and T. harzianum spore suspension (51\% and $54.33 \%$ ) alone at 7 and 14 DAS, respectively (Table 1 and Table 2).

Table-1: Effect of different combinations of $T$. harzianum on the germination (\%), damping off (\%) and foot rot (\%) of chilli at 7 DAS as affected by S. rolfsii and F. oxysporum

\begin{tabular}{|c|c|c|c|c|c|c|}
\hline \multirow[t]{2}{*}{ Treatments } & \multicolumn{3}{|l|}{ S. rolfsii } & \multicolumn{3}{|c|}{ F. oxysporum } \\
\hline & $\begin{array}{l}\text { Damping } \\
\text { off }(\%) *\end{array}$ & $\begin{array}{l}\text { Foot rot } \\
(\%)^{*}\end{array}$ & $\begin{array}{l}\text { Germination } \\
(\%) *\end{array}$ & $\begin{array}{l}\text { Damping } \\
\text { off }(\%) *\end{array}$ & $\begin{array}{l}\text { Foot rot } \\
(\%)^{*}\end{array}$ & $\begin{array}{l}\text { Germinati } \\
\text { on }(\%)^{*}\end{array}$ \\
\hline T. harzianum formulation & $3.67^{\mathrm{c}}$ & $3.67^{\mathrm{c}}$ & $59.00^{\mathrm{c}}$ & $7.67^{\mathrm{bc}}$ & $5.00^{\mathrm{c}}$ & $62.33^{\mathrm{c}}$ \\
\hline T. harzianum suspension & $5.33^{b}$ & $7.00^{b}$ & $51.00^{\mathrm{d}}$ & $8.67^{b}$ & $7.33^{b}$ & $54.67^{\mathrm{d}}$ \\
\hline $\begin{array}{l}\text { T. harzianum formulation }+ \\
\text { suspension }\end{array}$ & $1.00^{\mathrm{e}}$ & $1.33^{\mathrm{d}}$ & $80.67^{\mathrm{a}}$ & $2.00^{\mathrm{d}}$ & $1.00^{\mathrm{d}}$ & $83.33^{\mathrm{a}}$ \\
\hline Control (without pathogen) & $2.33^{\mathrm{d}}$ & $3.00^{c}$ & $71.33^{b}$ & $6.33^{\mathrm{c}}$ & $3.67^{\mathrm{c}}$ & $73.33^{b}$ \\
\hline Control (only pathogen) & $7.67^{\mathrm{a}}$ & $9.67^{\mathrm{a}}$ & $42.33^{\mathrm{e}}$ & $13.33^{\mathrm{a}}$ & $9.33^{\mathrm{a}}$ & $49.00^{\mathrm{d}}$ \\
\hline LSD & 1.24 & 1.409 & 5.40 & 1.69 & 1.627 & 6.63 \\
\hline $\mathrm{CV} \%$ & 17.08 & 15.70 & 4.87 & 12.25 & 16.98 & 5.64 \\
\hline
\end{tabular}

*The average of three replications; means followed by the same superscript letter in a column are not significant at $5 \%$ level by Duncan's multiple range test (DMRT).

In case of $F$. oxysporum inoculated plants, the combined application of formulated $T$. harzianum and its spore suspension was found to show minimum damping off (2\% and $2.67 \%)$ and foot rot $(1 \%$ and $2.33 \%)$ in comparison to the single application of formulated T. harzianum (7.67\% and $9.33 \%$ of damping off and $5 \%$ and $6.33 \%$ of foot rot); T. harzianum spore suspension $(8.67 \%$ and $10.67 \%$ of damping off and
$7.33 \%$ and $8.67 \%$ foot rot) at 7 and 14 DAS, respectively. The combined treatment also resulted the higher seed germination $(83.33 \%$ and $85.33 \%)$ in comparison to formulated T. harzianum $(62.33 \%$ and $64.67 \%)$ and, T. harzianum spore suspension $(54.67 \%$ and $59.67 \%$ ) alone at 7 and 14 DAS, respectively (Table 1 and Table 2).

Table-2: Effect of different combinations of T. harzianum on the germination (\%), damping off (\%) and foot rot (\%) of chilli at 14 DAS as affected by S. rolfsii and F. oxysporum

\begin{tabular}{|l|l|l|l|c|l|l|}
\hline \multirow{2}{*}{ Treatments } & \multicolumn{2}{|l|}{ S. rolfsii } & \multicolumn{2}{l|}{ F. oxysporum } \\
\cline { 2 - 7 } & $\begin{array}{l}\text { Damping } \\
\text { off }(\boldsymbol{\%})^{*}\end{array}$ & $\begin{array}{l}\text { Foot rot } \\
(\%)^{*}\end{array}$ & $\begin{array}{l}\text { Germination } \\
(\boldsymbol{\%})^{*}\end{array}$ & $\begin{array}{l}\text { Damping } \\
\text { off }(\boldsymbol{\%})^{*}\end{array}$ & $\begin{array}{l}\text { Foot rot } \\
(\%)^{*}\end{array}$ & $\begin{array}{l}\text { Germination } \\
(\%)^{*}\end{array}$ \\
\hline T. harzianum formulation & $4.67^{\mathrm{bc}}$ & $5.67^{\mathrm{c}}$ & $61.33^{\mathrm{c}}$ & $9.33^{\mathrm{bc}}$ & $6.33^{\mathrm{c}}$ & $64.67^{\mathrm{c}}$ \\
\hline T. harzianum suspension & $6.00^{\mathrm{b}}$ & $7.67^{\mathrm{b}}$ & $54.33^{\mathrm{d}}$ & $10.67^{\mathrm{b}}$ & $8.67^{\mathrm{b}}$ & $59.67^{\mathrm{d}}$ \\
\hline $\begin{array}{l}\text { T. harzianum formulation }+ \\
\text { suspension }\end{array}$ & $2.33^{\mathrm{d}}$ & $3.00^{\mathrm{d}}$ & $82.00^{\mathrm{a}}$ & $2.67^{\mathrm{d}}$ & $2.33^{\mathrm{d}}$ & $85.33^{\mathrm{a}}$ \\
\hline Control (without pathogen) & $3.33^{\mathrm{cd}}$ & $3.67^{\mathrm{d}}$ & $76.33^{\mathrm{b}}$ & $7.67^{\mathrm{c}}$ & $5.00^{\mathrm{c}}$ & $76.33^{\mathrm{b}}$ \\
\hline Control (only pathogen) & $9.33^{\mathrm{a}}$ & $11.67^{\mathrm{a}}$ & $45.00^{\mathrm{e}}$ & $14.67^{\mathrm{a}}$ & $11.67^{\mathrm{a}}$ & $51.33^{\mathrm{e}}$ \\
\hline LSD & 1.69 & 1.69 & 4.38 & 1.94 & 2.05 & 4.04 \\
\hline CV \% & 18.14 & 14.70 & 3.77 & 11.83 & 16.55 & 3.29 \\
\hline
\end{tabular}

*The average of three replications; means followed by the same superscript letter in a column are not significant at $5 \%$ level by Duncan's multiple range test (DMRT)

Along with the reduced damping off and foot rot, the single or combined use of formulated $T$. harzianum and its spore suspension was also remarkably increased the shoot length, root length, and vigor index caused by both $S$. rolfsii and $F$. oxysporum inoculated plants. The combined application of formulated T. harzianum and its spore suspension was increased shoot length by $91.58 \%$ and $31.99 \%$, root length by $65.84 \%$ and $28.66 \%$ and, vigor index by $233.13 \%$ and $117.77 \%$ in $S$. rolfsii and $F$. oxysporum inoculated plants, respectively at 14 DAS over control (Table 3). 
Table-3: Effect of different combinations of T. harzianum on the growth parameters of chilli at 14 DAS as affected by $S$. rolfsii and $F$. oxysporum

\begin{tabular}{|c|c|c|c|c|c|c|}
\hline \multirow[t]{2}{*}{ Treatments } & \multicolumn{3}{|l|}{ S. rolfsii } & \multicolumn{3}{|c|}{ F. oxysporum } \\
\hline & $\begin{array}{l}\text { *Shoot } \\
\text { length }(\mathrm{cm})\end{array}$ & $\begin{array}{l}* \text { Root } \\
\text { length }(\mathrm{cm})\end{array}$ & $\begin{array}{l}* \text { Vigor } \\
\text { index }(\%)\end{array}$ & $\begin{array}{l}\text { *Shoot } \\
\text { length }(\mathrm{cm})\end{array}$ & $\begin{array}{l}\text { *Root length } \\
\text { (cm) }\end{array}$ & $\begin{array}{l}* \text { Vigor } \\
\text { index }(\%)\end{array}$ \\
\hline T. harzianum formulation & $7.33^{b}$ & $3.23^{\mathrm{b}}$ & $648.8^{\mathrm{c}}$ & $6.83^{\mathrm{b}}$ & $3.60^{\mathrm{bc}}$ & $674.5^{\mathrm{c}}$ \\
\hline T. harzianum suspension & $6.90^{\mathrm{b}}$ & $3.16^{\mathrm{b}}$ & $546.9^{c}$ & $6.32^{\mathrm{c}}$ & $3.50^{\mathrm{c}}$ & $585.8^{\mathrm{d}}$ \\
\hline $\begin{array}{l}\text { T. harzianum formulation } \\
+ \text { suspension }\end{array}$ & $9.33^{\mathrm{a}}$ & $4.03^{\mathrm{a}}$ & $1097^{\mathrm{a}}$ & $7.88^{\mathrm{a}}$ & $3.95^{\mathrm{a}}$ & $1010^{\mathrm{a}}$ \\
\hline $\begin{array}{l}\text { Control (without } \\
\text { pathogen) }\end{array}$ & $7.17^{\mathrm{b}}$ & $3.70^{\mathrm{ab}}$ & $830.1^{b}$ & $7.17^{b}$ & $3.82^{\mathrm{ab}}$ & $838.8^{b}$ \\
\hline Control (only pathogen) & $4.87^{\mathrm{c}}$ & $2.43^{\mathrm{c}}$ & $329.3^{\mathrm{d}}$ & $5.97^{\mathrm{c}}$ & $3.07^{\mathrm{d}}$ & $463.8^{\mathrm{e}}$ \\
\hline LSD & 0.63 & 0.53 & 107.5 & 0.42 & 0.23 & 59.43 \\
\hline $\mathrm{CV} \%$ & 4.91 & 8.86 & 8.56 & 3.41 & 3.53 & 4.57 \\
\hline
\end{tabular}

*The average of three replications; means followed by the same superscript letter in a column are not significant at $5 \%$ level by Duncan's multiple range test (DMRT)

Different beneficial fungi and bacteria are considered as the major tools of biological control worldwide. However, the field application of biological controlling agents is getting popular for their effective and environmental friendly nature for the management of plant diseases in the last decade [18, 19]. Among the beneficial fungi, Trichoderma is one of the most effective and common biocontrol agents to manage crop diseases caused by Fusarium, Sclerotium, Rhizoctonia, Pythium, etc. [20]. Trichoderma can act against the plant pathogen in numerous ways including competition, antibiosis, mycoparasitism, inducing systemic host resistance, secretion, and production of chitinolytic enzymes, inhibitory compounds, etc. [21, 22]. Along with the super-fast growing ability in comparison to the other rhizospheric fungi, Trichoderma also secrets various enzymes like $\beta-1-3-$ glucanase, indole-3-acetic acid, gibberellins, siderophores, etc., which might have the suppressing ability of growth of the pathogens results in reduced plant diseases with increased plant growth [23-25]. In addition to the suppression of plant pathogens, the single or combined use of Trichoderma spp. also proved to increase the percent germination, shoot length, root length, and vigor index in various crop plants [26-28]. Moreover, Trichoderma spp. activates the plant's inherent immunity and enhances nutrient uptake efficiency from the soil, which may trigger higher plant growth and yield in crop plants [29].

\section{CONCLUSION}

From the study, it can be concluded that the natively isolated $T$. harzianum possessed strong antagonism against $S$. rolfsii and $F$. oxysporum responsible for damping off and foot rot in chilli when applied alone or in combination. In addition to the suppressing ability of the soil-borne pathogens, $T$. harzianum also promoted seed germination, plant height, weight, and vigor index of the crop plant. However, it is necessary to observe the field efficacy of the isolated indigenous $T$. harzianum before final recommendation to the farmers.

\section{REFERENCES}

1. BBS (Bangladesh Bureau of statistics). (2017). Yearbook of Agricultural Statistics-2017. Statistics and Information Division, Ministry of Planning, Government of the People's Republic of Bangladesh.

2. Ahmed, H. U., \& Hossain, M. M. (1985). Crop Disease Survey and Establishment of a Herbarium at BARI, Plant Pathology Division, Bangladesh Agricultural Research Institute, Joydebpur, Gazipur, 107.

3. Subash, N., Meenakshisundarm, M., \& Sasikumar, C. (2013). In-vitro evaluation of different strains of Trichoderma harzianum as bio-control agents of chilli. International Journal of Biology, Pharmacy and Allied Sciences, 2(2), 495-500.

4. Jayaraj, R., Megha, P., \& Sreedev, P. (2016). Organochlorine pesticides, their toxic effects on living organisms and their fate in the environment. Interdisciplinary Toxicology, 9, (3-4), 90-100.

5. Papavizas, G. V., \& Lumsden, R. D. (1980). Biological control of soil borne fungal propagules, Annual Review of Phytopathology, 18, 389-413.

6. Vinale, F., Sivasithamparam, K., Ghisalbertic, E. L., Marraa, R., Wooa, S. L., \& Loritoa, M. (2008). Trichoderma-plant-pathogen interactions. Soil Biology and Biochemistry, 40, 1-10.

7. Weindling, R. (1932). Trichoderma lignorum as a parasite of other soil fungi. Phytopathology, 22, 837-845.

8. Singh, S. P., Singh, H. B., \& Singh, D. K. (2013). Trichoderma harzianum and Pseudomonas sp. mediated management of Sclerotium rolfsii rot in tomato (Lycopersion esculentum Mill.). The Bioscan, 8(3), 801-804.

9. Singh, J., Kumar, V., Srivastava, S., Kumar, A. \& Singh, V. P. (2018). In vitro Evaluation of Trichoderma Species against Fusarium oxysporum f. sp. lycopersici Causing Tomato Wilt. Plant Pathology Journal, 17, 59-64.

10. Pal, K. K., \& McSpadden Gardener, B. (2006). Biological control of plant pathogens. The Plant 
Health Instructor. https://doi.org/10.1094/PHI-A2006-1117-02

11. Harman, G. E., Howell, C. R., Viterbo, A., Chet, I., \& Lorito, M. (2004). Trichoderma species opportunistic, a virulent plant symbiont. Nature Reviews Microbiology, 2, 43-56.

12. Barnett, H. L., \& Hunter, B. B. (1998). Illustrated genera of imperfect fungi. $4^{\text {th }}$ Ed. APS Press, St Paul, Minnesota.

13. Leslie, J. F., \& Summerell, B. A. (2006). The Fusarium laboratory manual. 1st Ed. Blackwell Publishing Ltd, Oxford, London.

14. Navaneetha, T., Prasad, R. D., \& Venkateswara, R. L. (2015). Liquid Formulation of Trichoderma Species for management of gray mold in Castor (Ricinus communis L.) and alternariaster leaf blight in Sunflower (Helianthus annuus L.). Journal of Biofertilizers \& Biopesticides, 6, 149.

15. Islam, M. N., Shamsuddula, A. M., \& Ahmed, H. P. (2007). Comparative effectiveness of Trichoderma colonized organic wastes in controlling foot and root rot (Sclerotium rolfsii) disease of wheat. African Crop Science Conference Proceedings, 8, 2079-2082.

16. Abdul-Baki, A. A., \& Anderson, J. D. (1973). Vigor determination in soybean by multiple criteria. Crop Science, 13(6), 630-633.

17. Gomez, K. A., \& Gomez, A. A. (1984). Duncan's Multiple Range Test, Statistical Procedure for Agril. Res. $2^{\text {nd }}$ Ed. A Wiley Inter-Science Publication, Johan and Sons, New York.

18. O'Brien, P. A. (2017). Biological control of plant diseases. Australasian Plant Pathology, 46, 293304.

19. Shahzad, S., Rajput, A. Q., \& Khanzada, M. A. (2018). Effect of different organic substrates and carbon and nitrogen sources on growth and shelf life of Trichoderma harzianum. Journal of Agricultural Science and Technology, 16, 731-745.

20. Al-Ani, L. K. T. (2019). Secondary metabolites of nonpathogenic Fusarium spp.; scope in agriculture. In: Singh, H. B., Keswani, C., Reddy, M. S., Royano, E. S., \& Garc1'a-Estrada, C. (Eds.) Secondary Metabolites of Plant Growth Promoting Rhizomicroorganisms - Discovery and Applications. Springer, Singapore, 59-76.

21. Harman, G. E., Howell, C. R., Viterbo, A., Chet, I., \& Lorito, M. (2004). Trichoderma species opportunistic, a virulent plant symbiont. Nature Reviews Microbiology, 2, 43-56.

22. Braun, H., Woitsch, L., Hetzer, B., Geisen, R., Zange, B., \& Schmidt-Heydt. M. (2018). Trichoderma harzianum: Inhibition of mycotoxin producing fungi and toxin biosynthesis. International journal of food microbiology, 280, 10-16.

23. Vinale, F., Sivasithamparam, K., Ghisalbertic, E. L., Marraa, R., Wooa, S. L., \& Loritoa, M. (2008). Trichoderma-plant-pathogen interactions. Soil Biology and Biochemistry, 40, 1-10.

24. Li, Y., Sun, R., Yu, J., Saravanakumar, K., \& Chen, J. (2016). Antagonistic and biocontrol potential of Trichoderma asperellum ZJSX5003 against the maize stalk rot pathogen Fusarium graminearum. Indian Journal of Microbiology, 56(3), 318-327.

25. Zhou, D., Huang, X. F., Guo, J., Dos-Santos, M. L., \& Vivanco, J. M. (2018). Trichoderma gamsii affected herbivore feeding behaviour on Arabidopsis thaliana by modifying the leaf metabolome and phytohormones. Microbial Biotechnology, 11(6), 1195-1206.

26. Mahdizadehnaraghi, R., Heydari, A., Zamanizadeh, H. R., Rezaee, S., \& Nikan, J. (2015). Biological control of garlic (Allium) white rot disease using antagonistic fungi-based bioformulations. Journal of Plant Protection Research, 55(2); 136-141.

27. Hajieghrari, B., \& Mohammadi, M. (2016). Growth-promoting activity of indigenous Trichoderma isolates on wheat seed germination, seedling growth and yield. Australian Journal Crop Science, 10(9), 1339-1347.

28. Uddin, M. N., Rahman, U., Khan, W., Uddin, N., \& Muhammad, M. (2018). Effect of Trichoderma harzianum on tomato plant growth and its antagonistic activity against Pythium ultimum and Phytophthora capsici. Egyptian Journal of Biological Pest control, 28, 32.

29. Wonglom, P., Daengsuwan, W., Ito, S. I., \& Sunpapao, A. (2019). Biological control of Sclerotium fruit rot of snake fruit and stem rot of lettuce by Trichoderma sp. T76- $12 / 2$ and the mechanisms involved. Physiological and Molecular Plant Pathology, 107, 1-7.

Cite This Article: Mukul Islam et al (2021). Biological Control of Damping off and Foot Rot of Chilli Using an Indigenous Trichoderma Harzianum. East African Scholars J Agri Life Sci, 4(4), 101-105. 